\title{
Energy requirements in a technified poultry farm in Central Mexico
}

\author{
A. Arroyo-Pitacua ${ }^{1}$, L. Márquez-Benavides ${ }^{1} \&$ E. L. Moreno-Goytia ${ }^{2}$ \\ ${ }^{1}$ Universidad Michoacana de San Nicolás de Hidalgo, México \\ ${ }^{2}$ Instituto Tecnológico de Morelia, México
}

\begin{abstract}
Mexico is one the leading poultry producers worldwide (4th place). Although poultry farming has the largest share from the total Mexican national livestock, its contribution to Mexico's GHG national inventories account are neither well defined by level of technification or region nor particularized by contributor energy consumption for instance - and well characterized. Aiming to reduce this information gap, this work evaluates the electrical and gas energy requirements in a technified poultry farm located in Michoacán, Mexico, thoroughly dedicated to meat production. In the first sections, the paper describes the selected poultry farms and evaluates the energy consumption inventory and the respective $\mathrm{CO}_{2} \mathrm{eq}$ are calculated. Afterwards, the results of this research are presented, and a comparative discussion of the results are carried out. A critical analysis of the data highlights the relevance of LP gas usage in this farm and the necessity to include the $\mathrm{CO}_{2}$ emission from this activity to the national greenhouse emissions. Keywords: $\mathrm{CO}_{2}$ emissions, electricity usage, efficiency, energy productivity.
\end{abstract}

\section{Introduction}

Mexico ranks 12th in the world in relation to $\mathrm{CO}_{2}$ emissions, that is, it contributes $1.5 \%$ of the total of global emissions. From the total national emissions in Mexico, approximately $12 \%$ is contributed by the agricultural sector. This category is constituted by the emissions produced by the agricultural sector (crops and soil management) and livestock activities (enteric fermentation and manure management) [1]. From the total Mexican national livestock category, poultry faming contributes with a $63 \%$. In fact, Mexico is the $4^{\text {th }}$ poultry producer worldwide [2] producing both meat and eggs and according 
to FAO, Mexico produces $3 \%$ of the poultry world production. This activity is represented by various levels of technification and profitability. The Mexican Poultry National Union (UNA, in Spanish) states that in 2013 meat poultry production was 3 million tonnes. Any livestock process represents an environmental impact towards water and soil, but also they are regarded as important sources of greenhouse gases (GHG) emissions. The agriculture category of Mexico's GHG national inventories account for activities such as the application nitrogen fertilizers, burning of agriculture wastes, livestock activities such as enteric fermentation and manure management, however, all the rest livestock activities are concentrated in these latter categories and there is no indication on the particular contribution of poultry farming in this category [1].

Technified poultry farms demand relatively large amounts of energy to provide thermal comfort, appropriate illumination levels, food dispensing, automated ventilation, water providing, etc. [3]. The aim of this work was to evaluate the electric energy requirements in a technified poultry farm dedicated to meat production, as this information is widely unknown in Mexico.

\section{Methodology}

\subsection{Area of study}

The studied farm was located in the Taretan municipality, in the Michoacán state, Mexico (see fig. 1). The coordinates of the area are $19^{\circ} 20^{\prime} 00^{\prime \prime} \mathrm{N}$ $101^{\circ} 55^{\prime} 00^{\prime \prime} \mathrm{O}$. Its climate is tempered with rains in summer. It has an annual rainfall of $1560 \mathrm{~mm}$ and temperatures ranging from 4.4 to $29.6^{\circ} \mathrm{C}$. The study was carried out during the summer of 2013.

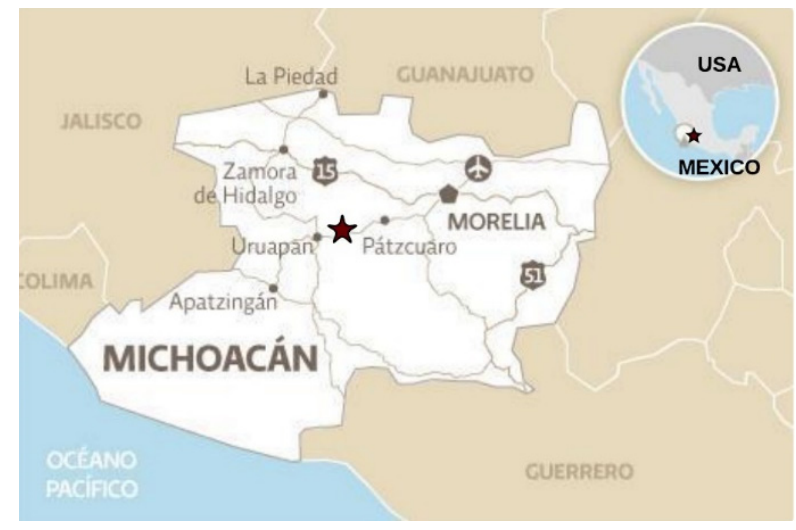

Figure 1: Localization map of the studied area in central Mexico.

\subsection{Farm description and process study}

The farm belongs to one of the largest companies in the area, as they are in charge of the meat poultry production for part of Michoacán and Guerrero, its 
neighboring state. It has several farms scattered in the Taretan area, but only one of those complex was studied. This particular farm consisted of ten poultry houses (13 m width x $150 \mathrm{~m}$ length), each one with a capacity of 22,000 chickens per cycle. Fig. 2 shows the general layout of the farm, showing electrical and water supply. The farm is technified, poultry houses have a controlled environment as heating systems, extractors, cooling fans, fogging cooling, moisture control and automated shutters are in place.

The main inputs/outputs for the process were declared by the assisting staff, i.e. food portions, volume of supplied water, number of birds per cycle, weight of birds at the end of the process, LP gas, electricity usage, etc. Then, an operational diagram for the farm was constructed, including the lighting, machinery and equipment used for the production system. The full process was also studied in order to identify the particular phases during which particular equipment was intensively used, such as the heating systems that are used only at the initial stages of the process. A total calculation base of 1000 chickens was used for the report.

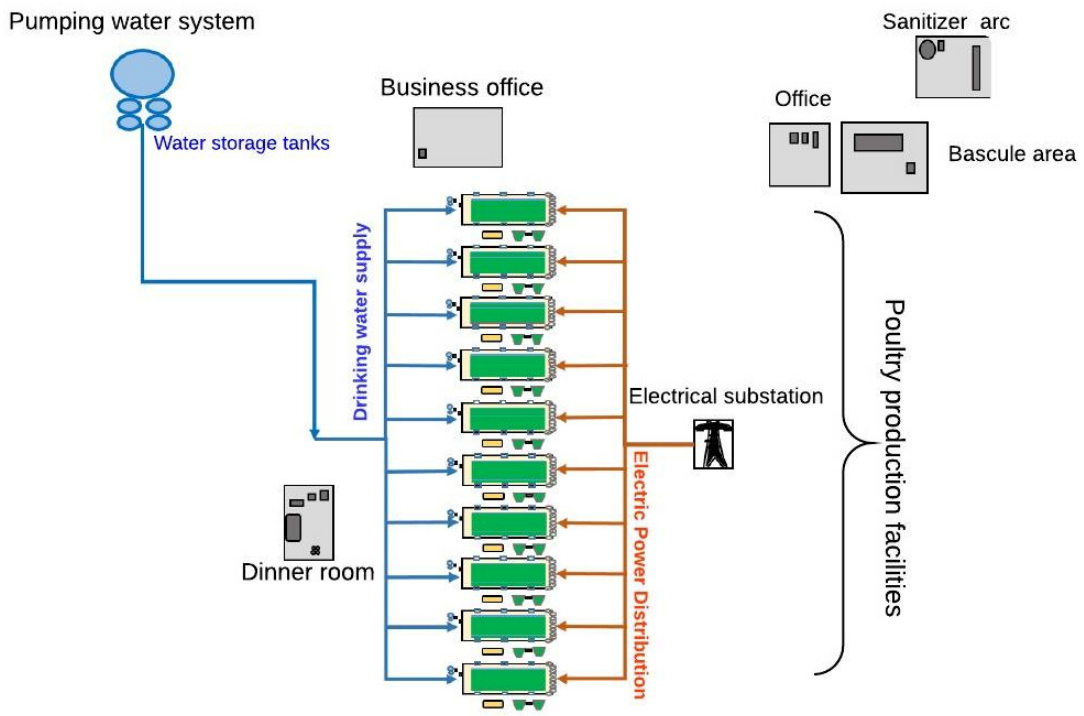

Figure 2: General layout of the chicken farm.

\subsection{Electricity usage and calculation factors}

\subsubsection{Water supply}

The farm has a well $\left(105.2 \mathrm{~m}^{3}\right)$ that is used to pump water to the automated poultry water fountains. In the state of Michoacán, and according to the CONUEE [4], the Michoacan's Efficiency Index (MEI) is $0.75 \mathrm{kWh} / \mathrm{m}^{3}$. That is, it represents the electrical energy usage to extract and distribute potable water $\left(1 \mathrm{~m}^{3}\right)$. 


\subsubsection{Lighting and equipment inventory}

As stated, an inventory of equipment and machinery present in the poultry houses, along with the respective electrical requirement was carried out. In order to evaluate the corresponding $\mathrm{CO}_{2}$ emissions, an emission factor of $454 \mathrm{~g}$ of $\mathrm{CO}_{2} \mathrm{eq} / \mathrm{kWh}$ was used.

\subsubsection{Production energy efficiency}

The ratio productivity/energy input was calculated using eqn. (1) as proposed by [5]

$$
\text { Energy productivity }(\mathrm{EP})=\frac{\text { Chicken weight }(\mathrm{kg})}{\text { energy input }(\mathrm{MJ})}
$$

\section{Results and discussion}

\subsection{Farm production process}

A general diagram for the poultry farm process was generated in order to show input and output variables, along with the electricity requirements in the process (fig. 3). It is important to point out that only the chicken meat production was assed. Other important process such as slaughtering, food production, meat distribution, solid waste management were not included.

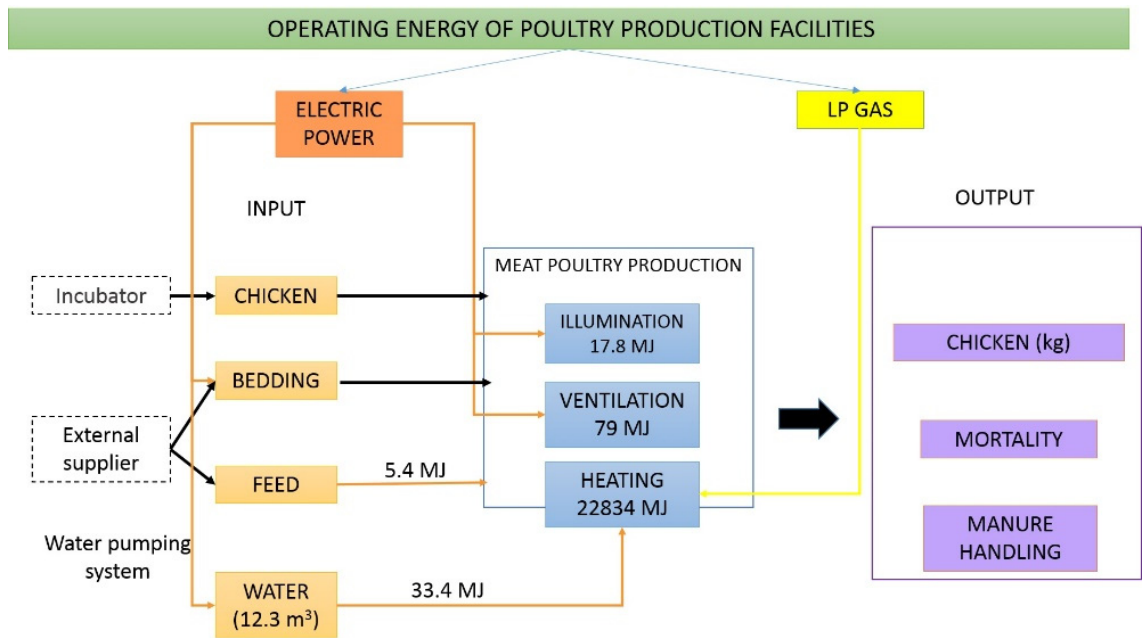

Figure 3: General input and output variables at the poultry farm.

Electricity demand varies during the process, according to the age and development of the chickens. Table 1 shows the difference among water demand and subsequent electricity usage. The last week of the process requires the largest water volume $\left(4.4 \mathrm{~m}^{3}\right)$ for 1000 chickens. 
Table 1: Water demand and the associate energy requirements during the cycle (49 days) of chicken meat production in the Taretan farm (1000 chickens).

\begin{tabular}{|c|c|c|c|}
\hline Process phase (week) & $\mathrm{m}^{3}$ & $\mathrm{kWh}$ & $\mathrm{MJ}$ \\
\hline 1 & 0.2 & 1.2 & 0.7 \\
\hline 2 & 0.6 & 0.4 & 1.7 \\
\hline 3 & 1.1 & 0.8 & 3.1 \\
\hline 4 & 1.3 & 1.0 & 3.6 \\
\hline 5 & 1.9 & 1.4 & 5.2 \\
\hline 6 & 2.5 & 1.8 & 6.7 \\
\hline $7 \quad$ Total & 4.4 & 3.4 & 12.0 \\
\hline \multicolumn{2}{r|}{} & 9.3 & 33.4 \\
\hline
\end{tabular}

Once the information of the process was obtained, the emissions were calculated for every category of electricity usage (Table 2). The main category contributing to $\mathrm{CO}_{2}$ eq emissions corresponded to the usage of LP gas in the heating system. Obtained results indicate that the electricity and LP gas required for a full cycle (49 days) to produce 1000 chickens amounts to $1206.4 \mathrm{~kg} \mathrm{CO}$ eq. Therefore, the Energy Productivity (Eqn. 1) for a full production cycle at the Taretan farm is:

$$
E P=\frac{2549.4 \mathrm{~kg} \text { live weight }}{23354.6 \mathrm{MJ}}=0.12 \mathrm{~kg} / \mathrm{MJ}
$$

Other reports [6] state that the EP calculated for Iranian poultry producers was $0.01 \mathrm{~kg} / \mathrm{MJ}$, suggesting that $0.01 \mathrm{~kg}$ of bird meat was expected per $1 \mathrm{MJ}$ energy used. The difference is likely to be accounted for due to the fact that the Iranian poultry process included a larger delimitation of the study and additional process were taken in account.

Table 2: Energy and associated $\mathrm{CO}_{2}$ eq emissions during the chicken meat production (1000 chickens).

\begin{tabular}{|c|c|c|}
\hline Category & MJ & Emissions $\mathrm{kgCO}_{2} \mathrm{eq}$ \\
\hline Potable water pumping and distribution & 33.4 & 4.2 \\
\hline Heating (LP gas) & 22834 & $1,156.6$ \\
\hline Lighting & 17.8 & 2.2 \\
\hline Food distribution & 5.4 & 2.4 \\
\hline Ventilation & 79 & 9.9 \\
\hline Hot air extraction & 385 & 32.7 \\
\hline TOTAL & 23354.6 & $1,206.4$ \\
\hline
\end{tabular}


To the best knowledge of the authors, there is a scarcity of reports on energy demand for the poultry sector in Mexico. First, there is no official and detailed listing of existing farms. Only the states of Jalisco and Puebla are listed as the main producers nationwide. There is no public information on the level of technification of Mexican poultry farms and specific energy requirements are widely unknown. The implication of this is that the poultry sector is not yet able to plan and aim for energy efficiency strategies, that might save up to $15 \%$ in costs related to fossil derived energy [6]. Secondly, the additional implication is that the contribution to $\mathrm{CO}_{2}$ emissions by the Mexican poultry sector are not only unknown but grossly disregarded when considering that Mexico is the $4^{\text {th }}$ world producer. Furthermore, two important considerations need to be in place. On the one hand, international reports from developed countries (see Table 3) describe farms usually located in regions with extreme weathers, whereas Mexico's principal poultry areas (Jalisco and Puebla States) are never faced with either harsh winters or extreme hot weathers. As opposed to those available reports, poultry husbandry in Mexico is not likely to have the largest demand on electricity for air temperature conditioning, but rather rely heavily on the demand of LP gas for early stages of chicks (Table 4). Lastly, a word of caution about our results just presented. Our scope was limited because food production was not taken into consideration. Several reports indicate that the process of food production for poultry husbandry is highly demanding on energy [7] as it requires $80 \%$ of the global energy chain. The results shown in Table 3 are the smallest for both live and slaughtered weight, but real comparisons are difficult

Table 3: $\quad \mathrm{CO}_{2}$ eq emissions of different process of poultry meat production (live weight).

\begin{tabular}{|c|c|}
\hline Reference & $\begin{array}{c}\mathrm{kg} \mathrm{CO} \text { eq } / \mathrm{kg}, \\
\text { slaughtered }\end{array}$ \\
\hline This work & $0.47^{\mathrm{a}}$ \\
\hline This work & $0.7^{\mathrm{b}}$ \\
\hline$[8]$ & 4.57 \\
\hline$[9]$ & $2.6^{\mathrm{b}}$ \\
\hline$[10]$ & $1.5^{\mathrm{b}}$ \\
\hline$[11]$ & $7.3^{\mathrm{b}}$ \\
\hline
\end{tabular}

${ }^{a}$ Based on $1.7 \mathrm{~kg}$ as average weight for slaughtered chickens, slaughtered weight, blive weight. 
to produce because the system boundaries in each report differ, as well as environmental conditions and management practices. Thus, comparison with other livestock practices are also problematic (Table 4) but it is necessary for developing countries to generate a reliable database. In Table 4 it is evident that poultry and cattle energy demand have different categories, and comparisons should be carefully made. LP gas was detected to be the main demand for poultry meat production in Mexico, and it is likely to be the case in other region with similar weather and technification conditions.

Table 4: Energy requirements for animal husbandry (live weight).

\begin{tabular}{|c|c|c|c|}
\hline Category & Chicken $^{\mathrm{a}} \mathrm{MJ} / \mathrm{kg}$ & $\mathrm{Pig}^{\mathrm{b}} \mathrm{MJ} / \mathrm{kg}$ & Cattle $^{\mathrm{c}} \mathrm{MJ} / \mathrm{kg}$ \\
\hline Electricity & & & 2.34 \\
\hline Potable water & 0.01 & 0.02 & - \\
\hline Lighting & 0.01 & 0.05 & - \\
\hline Food & 0.002 & 0.02 & - \\
\hline Ventilation & 0.03 & 0.20 & - \\
\hline Heat Extraction & 0.15 & - & - \\
\hline High-pressure washing & - & 0.03 & - \\
\hline Auxiliary heating & - & 0.19 & - \\
\hline \multicolumn{4}{|l|}{ LP Gas } \\
\hline Heating & 8.96 & 0.81 & - \\
\hline Diesel & & & 7.92 \\
\hline Manure management & - & 0.02 & - \\
\hline Water Heating & - & 0.12 & - \\
\hline TOTAL & 9.2 & 1.45 & 10.26 \\
\hline
\end{tabular}

${ }^{\mathrm{a}}$ This work; ${ }^{\mathrm{b}}[12] ;{ }^{\mathrm{c}}[13]$.

\section{Conclusions}

Poultry meat production in central Mexico currently relies heavily in fossil energy, particularly LP gas. This sector is likely to contribute significantly to greenhouse emissions but there is an important data void on $\mathrm{CO}_{2}$ emission from an official point of view. Weather conditions for the largest poultry farms in Mexico are not harsh, therefore there is a significant chance to generate energy saving programs in the region. 


\section{Acknowledgements}

The generous funding of both the CIC-UMSNH project 2014-2015 authorized to Dr. L. Marquez, and the DGEST project 5584.15-P, as well as PROMEP, are gratefully acknowledged. Also, the funding derived from the program PROFOCIE 2014-16MSU0014T-10 at the UMSNH for travelling expenses is appreciatively recognized.

\section{References}

[1] INEGEI 1990-2010, 2010, Quinta Comunicación Nacional ante la CMNUCC, National Institute of Ecology (In Spanish), México.

[2] Nguyen, T.T.H., Bouvarel, I., Ponchant, P., Hayo, M.G. \& Werf, V.D., Using environmental constraints to formulate low-impact poultry feeds. Journal of Cleaner Production, 28, 215-224, 2012.

[3] Oviedo-Rondon E., Ahorro energético en granjas avícolas, (Energy savings in poultry farms, in Spanish) Proc. of the XLVII Symposium Cientifico de Avicultura, Zaragoza 2009.

[4] Estudio Integral de Sistemas de Bombeo de Agua Potable Municipal (Potable Water Municipal Water Pumping Systems, In Spanish); CONUUE, SENER, Cooperación Alemana al Desarrollo, México, D.F.

[5] Salazar M. Cruz. R. \& Rojano P., Eficiencia en el uso de la energía en invernaderos mexicanos (Energy efficiency in Mexican greenhouses, In Spanish). Revista Mexicana de Ciencias Agrícolas, 4(6), pp. 736-742, 2012.

[6] Sefat M., Borgaee A., Beheshti B. \& Bakhoda H., Modelling Energy Efficiency in Broiler Chicken Production Units Using Artificial Neural Network (ANN). International Journal of Natural and Engineering Sciences, 8 (1), pp. 07-14, 2014.

[7] Pelletier, N., Environmental performance in the US broiler poultry sector: life cycle energy use and greenhouse gas, ozone depleting, acidifying and eutrophying emissions. Agricultural Systems, 98(2), pp. 67-73, 2008.

[8] Roy, P., Orikasa, T., Thammawong, M., Nakamura, N., Xu, Q., \& Shiina, T., Life cycle of meats: an opportunity to abate the greenhouse gas emission from meat industry in Japan. Journal of environmental management, 93(1), 218-24, 2011.

[9] Cederberg, C., Flysjö, A., Sonesson, U., Sund, \& V., Davis, J., Greenhouse Gas Emissions from Swedish Consumption of Meat, Milk and Eggs 1990 and 2005. SIK Report 793. The Swedish Institute for Food and Biotechnology, 2009.

[10] Thynelius, G. Klimatpåverkan och förbättringsåtgärder för Lantmännens livsmedel - fallstudie Kronfågels slaktkyckling (Climate Impact and Improvement potentials for Lnatmännen's chicken, Kronfågels case, in Swedish) Dept. of Technology and Society, Environmental and Energy Systems Studies, Lund University, Lund, Sweden. 
[11] Determining the environmental burdens and resource use in the production of agricultural and horticultural commodities, Main Report, Defra Research project IS0205, Bedford: Cranfield University and Defra, 2006, www.silsoe.cranfield.ac.uk

[12] Energy and carbon inventory of Iowa swine production facilities; Leopold Center for Sustainable Agriculture, Iowa State University, 2010, www.leopold.iastate.edu/pubs-and-papers/2010-06-energy-and-carboninventory-iowa-swine-production-facilities.

[13] Greenhouse gas emissions in chicken production. Decision support for climate certification; Klimatcertifiering för Mat (Climate Certification for Food, in Swedish); www.klimatmarkningen.se/wp-content/uploads/ 2009/12/2009-6-chicken.pdf 